\title{
PERANCANGAN SUHU TERMAL RUANG KULIAH DENGAN MEMERHATIKAN BEBAN AKTIVITAS, SENSASI TERMAL DAN TERMAL ACCEPTABILITY: STUDI KASUS PADA UNIVERSITAS ATMA JAYA YOGYAKARTA
}

\author{
Parama Kartika Dewa ${ }^{1}$, Novenda Kartika Putrianto ${ }^{2}$ \\ Program Studi Teknik Industri, Fakultas Teknologi Industri, Universitas Atma Jaya Yogyakarta \\ Jl. Babarsari 43, Yogyakarta 55281 \\ Email: parama.dewa@uajy.ac.id, novenda@msn.com
}

\begin{abstract}
ABSTRAK
Riset perancangan suhu termal selama ini berfokus kepada desain dan evaluasi ruang pada gedung yang diperuntukkan untuk kegiatan perkantoran, tempat tinggal, dan kegiatan manufaktur. Faktor yang dominan diperhatikan adalah jumlah pengguna dalam ruang, temperatur dalam ruang, dan kelembaban udara dalam ruang. Perancangan suhu termal untuk ruang kelas tidak banyak ditemukan dalam literatur, terutama dengan memerhatikan beban aktivitas, sensasi termal dan termal acceptability. Penelitian ini bertujuan untuk merancang suhu termal yang ideal pada ruang kelas di Universitas Atma Jaya Yogyakarta dengan memerhatikan beban aktivitas, sensasi termal, dan termal acceptability. Proses untuk mengidentifikasi suhu kenyamanan termal pada saat mahasiswa melakukan aktivitas kuliah menjadi penting untuk dilaksanakan. Hasil ini diharapkan menjadi masukan bagi tahapan penelitian berikutnya terkait dengan pengukuran energi yang diperlukan untuk menjadikan kondisi termal tersebut terwujud di ruang kuliah UAJY. Lokasi penelitian dilakukan di ruang kuliah Fakultas Teknologi Industri UAJY. Subjek penelitian adalah 120 mahasiswa. Periode waktu pengambilan data dilakukan sebanyak dua periode setiap pengambilan data. Proses pengukuran data dan hasil dilakukan secara langsung di ruang kuliah. Suhu ruang diatur pada alternative $19^{\circ} \mathrm{C}, 23^{\circ} \mathrm{C}, 27^{\circ} \mathrm{C}$ dan $30^{\circ} \mathrm{C}$. Hasil penelitian berdasarkan analisis sensasi termal dan analisis thermal acceptability merekomendasikan suhu ruang kuliah dikondisikan $23^{\circ} \mathrm{C}$ akan menjamin kenyamanan mahasiswa saat mengikuti kuliah dalam kondisi baik.
\end{abstract}

Kata kunci: kenyamanan, suhu, termal, aktivitas kuliah

\begin{abstract}
Research on thermal temperature design has so far focused on the design and evaluation of spaces in buildings devoted to office, residential and manufacturing activities. The dominant factor is the number of users in the room, the temperature in the room, and the humidity in the room. The design of thermal temperatures for classrooms is not much found in the literature, especially concerning activity loads, thermal sensations, and thermal acceptability. This study aims to design an ideal thermal temperature in the classroom at Atma Jaya University Yogyakarta by observing the activity load, thermal sensation, and thermal acceptability. The process of identifying the temperature of thermal comfort when students conduct lecture activities is important to be carried out. This result is expected to be the input for the next stage of research related to the energy measurement needed to make the thermal condition materialized in the UAJY lecture room. The location of the study was conducted in the lecture room of the UAJY Faculty of Industrial Technology. The subjects were 120 students. Period of data retrieval time is done as much as two periods each data retrieval. The process of measuring data and results is done directly in the lecture hall. Room temperature is adjusted to other temperatures of $19^{\circ} \mathrm{C}, 23^{\circ} \mathrm{C}, 27^{\circ} \mathrm{C}$ and $30^{\circ} \mathrm{C}$. The results of the research based on thermal sensation analysis and thermal acceptability analysis recommend the conditioned room temperature $23{ }^{\circ} \mathrm{C}$ which will ensure the comfort of students while attending the lecture in excellent condition.
\end{abstract}

Keywords: comfort, temperature, thermal, lecture activity

\section{Pendahuluan}

Pendidikan merupakan hal penting dalam menjamin keberlangsungan kinerja suatu negara, khususnya dalam mempersiapkan generasi penerus bangsa. Proses untuk menyelenggarakan pendidikan tinggi memegang peran penting pada satu sisi dan pada sisi yang lain bagaimana kegiatan proses pendidikan berlangsung dalam kondisi 
yang nyaman. Kenyamanan lingkungan (belajar) suatu ruangan adalah faktor penting yang memengaruhi hasil belajar sehingga penting untuk mengondisikan ruangan senyaman mungkin [1]. Faktor kenyamanan lingkungan yang berpengaruh terhadap kenyamanan seseorang saat beraktivitas adalah kenyamanan termal. Produktifitas manusia cenderung menurun pada kondisi udara yang tidak nyaman seperti terlalu dingin atau terlalu panas dan meningkat pada kondisi suhu yang nyaman [2].

Studi mengenai pengaruh kualitas kenyamanan termal di suatu ruangan terhadap performansi siswa sudah dilakukan sejak pertengahan tahun 1950an. Kenyamanan termal didefinisikan sebagai persepsi pikiran yang mengungkapkan kepuasan terhadap keadaan termal lingkungan [3]. Suatu kondisi ruang dinyatakan nyaman apabila dominan pengguna menyatakan kondisi nyaman secara termal [4]. Penelitian ini semakin berkembang sejak munculnya teori Fanger mengenai kenyamanan termal berdasarkan hasil dari suhu ruangan terkontrol [5]. Minat pada studi tentang teori adaptif yang semakin berkembang di tahun-tahun terakhir ini telah merangsang penelitian mengenai kenyamanan termal dengan melakukan studi lapangan [6, 7].

Faktor yang memengaruhi kenyamanan dalam suatu ruang adalah temperatur udara dalam ruang, kelembaban udara, temperatur radiasi rata-rata ruang, sirkulasi udara, tingkat pencahayaan, dan distribusi cahaya pada dinding [8]. Kenyamanan termal ruangan dapat dicapai dengan mengatur suhu ruangan sesuai keinginan pengguna, salah satunya penggunaan Air Conditioner (AC). Semua ruang kuliah yang digunakan oleh mahasiswa UAJY sudah difasilitasi dengan AC. Penggunaan AC dalam ruangan bertujuan untuk memenuhi kenyamanan termal pengguna sehingga pengguna dapat mencapai produktivitasnya [9]. Hampir sebagian besar aktivitas perkuliahan di UAJY dilakukan di dalam ruang kuliah. Pengaturan suhu AC dalam ruang kuliah untuk memenuhi kenyaman termal bagi mahasiswa sangat penting dilakukan. Penggunaan AC memerlukan energi yang tidak sedikit tergantung pada pengaturan mesin AC. Universitas Atma Jaya Yogyakarta berencana mengelola proses pendidikan dilakukan dengan baik, sehingga bagaimana menyusun kebijakan terkait aktivitas kuliah agar nyaman perlu dikaji lebih lanjut. Kondisi ini menimbulkan kebutuhan penelitian mengenai lingkungan termal dalam ruang kuliah, pada suhu ruangan berapakah pengguna merasa nyaman didalam ruangan. Penelitian mengenai lingkungan termal dalam ruang kuliah dibutuhkan karena kualitas udara dalam ruangan berpengaruh terhadap efisiensi intelektual dan kesehatan pengguna ruangan [10].

Respon kenyamanan termal pada manusia tergantung pada beberapa faktor salah satunya adalah beban aktivitas [11]. Jenis aktivitas yang berbeda memiliki beban aktivitas yang berbeda juga. Aktivitas dengan beban kerja berat berbeda dengan aktivitas ringan terkait dengan produksi panas tubuh dan proses regulasi termal. Riset perancangan suhu termal selama ini berfokus kepada desain dan evaluasi ruang pada gedung yang diperuntukkan untuk kegiatan perkantoran, tempat tinggal dan kegiatan manufaktur. Faktor yang dominan diperhatikan adalah jumlah pengguna dalam ruang, temperatur dalam ruang, dan kelembaban udara dalam ruang. Perancangan suhu termal untuk ruang kuliah tidak banyak ditemukan dalam literatur, terutama dengan memerhatikan beban aktivitas, sensasi termal dan termal acceptability.

Aktivitas mahasiswa UAJY di ruang kuliah adalah kegiatan belajar mengajar dan kuis atau ujian. Keluaran penelitian berupa identifikasi suhu kenyamanan termal pada saat mahasiswa melakukan kedua aktivitas tersebut. Hasil ini diharapkan menjadi masukan bagi tahapan penelitian berikutnya terkait dengan pengukuran energi yang diperlukan untuk menjadikan kondisi termal tersebut terwujud di ruang kuliah UAJY. Penelitian ini merupakan salah satu rangkaian penelitian yang dilakukan untuk menyusun kebijakan terkait dengan penggunaan energi di lingkup UAJY.

\section{Metode Penelitian}

Penelitian ini dilaksanakan dengan pendekatan penelitian eksperimen. Penelitian eksperimen adalah penelitian yang melakukan kajian varian dari semua variabel bebas yang berpengaruh dengan memberikan dampak yang seminim mungkin terhadap variabel yang tidak relevan dengan kajian yang diteliti [12]. Penelitian menggunakan pendekatan ini karena kondisi kenyamanan yang dipersepsikan oleh manusia dipengaruhi oleh banyak faktor yang ada di dalam maupun di luar manusia sehingga diperlukan perlakuan tertentu untuk mengidentifikasikan suhu termal yang sesuai.

Lokasi penelitian untuk pengambilan data dilakukan di ruang kuliah Fakultas Teknologi Industri (FTI) Universitas Atma Jaya Yogyakarta. Pemilihan lokasi ini disebabkan lokasi gedung, bentuk gedung, dan desain ruang kuliah dapat mewakili kondisi ruang kuliah yang dominan ada di lingkup UAJY. Subjek penelitian adalah 120 mahasiswa Universitas Atma Jaya Yogyakarta. Penelitian dilakukan di ruang kuliah Fakultas Teknik Industri UAJY dengan dua periode pengambilan data yaitu pada pukul 9.45 - 12.15 dan $15.30-18.00$. Metode penelitian ini meliputi pengukuran langsung dilakukan di ruang kuliah. Eksperimen dilakukan pada ruang kondisi dengan AC di dalamnya. Temperatur ruangan diatur mulai dari $19^{\circ} \mathrm{C}-28^{\circ} \mathrm{C}$. Uji kenyamanan termal dilakukan pada setiap 15 
mahasiswa (8 laki-laki dan 7 perempuan). Jumlah subjek ini ditentukan berdasarkan acuan [13] di mana selama 50 tahun penelitian mengenai kenyamanan termal manusia minimum subjek yang digunakan adalah 6 orang. Subjek tersebut melakukan aktivitas yang berbeda seperti memerhatikan dosen dan mencatat pelajaran, mengoperasikan komputer, menyelesaikan ujian. Kelembaban udara dicatat setiap 15 menit sehingga diperoleh kelembaban udara rata-rata. Subjek melakukan aktivitas perkuliahan seperti biasa selama 80 menit kemudian dilanjutkan kuis selama 10 menit. Subjek menggunakan jenis pakaian yang mirip pada setiap percobaan, yaitu kemeja katun lengan pendek, celana jeans, kaos kaki, dan sepatu tertutup rapat. Kuesioner dibagikan kepada subjek dan subjek menuliskan sensasi kenyamanan termal berdasarkan situasi yang dialami oleh subjek itu sendiri. Skala yang digunakan menggunakan tujuh skala kenyamanan termal berdasarkan ASHRAE (2004) yaitu dingin, sejuk, agak sejuk, netral, agak hangat, hangat, dan panas [14]. Alat yang digunakan untuk mendukung penelitian ini adalah termometer ruangan dan higrometer.

Lokasi sensor temperatur kulit akan diletakkan di dahi, bahu kanan dan kiri, lengan kanan dan kiri, pergelangan tangan kanan dan kiri, paha kanan dan kiri, serta pergelangan kaki kanan dan kiri. Prosedur eksperimen adalah subjek memasuki lingkungan kondisi selama 10 menit untuk uji aklimatisasi dengan suhu ruangan.

\section{Hasil dan Pembahasan}

\section{Analisis Sensasi Termal pada Pengaturan Suhu Ruang $19^{\circ} \mathrm{C}$}

Sensasi termal terhadap kenyamanan termal memiliki skala antara -3 (untuk sensasi dingin) sampai +3 (untuk sensasi panas). Pada Gambar 1, terdapat 62\% responden menunjukkan respon merasa kedinginan, 29\% menunjukkan respon merasa sejuk dan $9 \%$ menunjukkan respon merasa agak sejuk, baik untuk aktivitas kuis dan kuliah biasa. Pada Gambar 2, terdapat 23\% responden menunjukkan respon merasa kedinginan, 44\% menunjukkan respon merasa sejuk dan $34 \%$ menunjukkan respon merasa agak sejuk, baik untuk aktivitas kuis dan kuliah biasa. Menurut standard ASHRAE 55-2004, spesifikasi mengenai penerimaan kenyamanan termal harus mencapai $80 \%$ dari voting responden di skala $(-1,0,1)$. Dalam studi ini, dapat disimpulkan pengaturan suhu ruangan $19^{\circ} \mathrm{C}$ dengan kelembaban udara $53 \%$ maupun $58 \%$ merupakan kondisi suhu yang tidak dapat diterima.

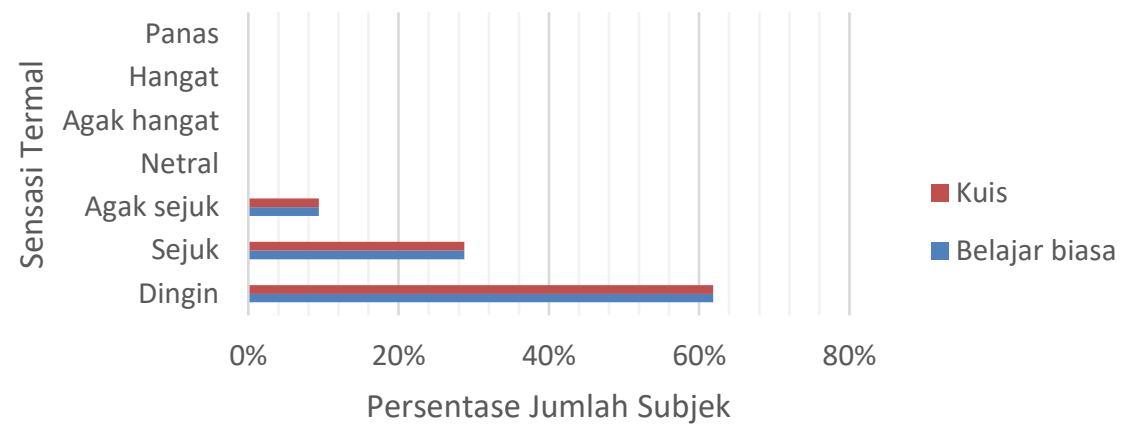

Gambar 1. Persentase distribusi subjek mengenai sensasi termal di pagi hari (suhu ruang $19^{\circ} \mathrm{C}, \mathrm{RH} 53 \%$ )

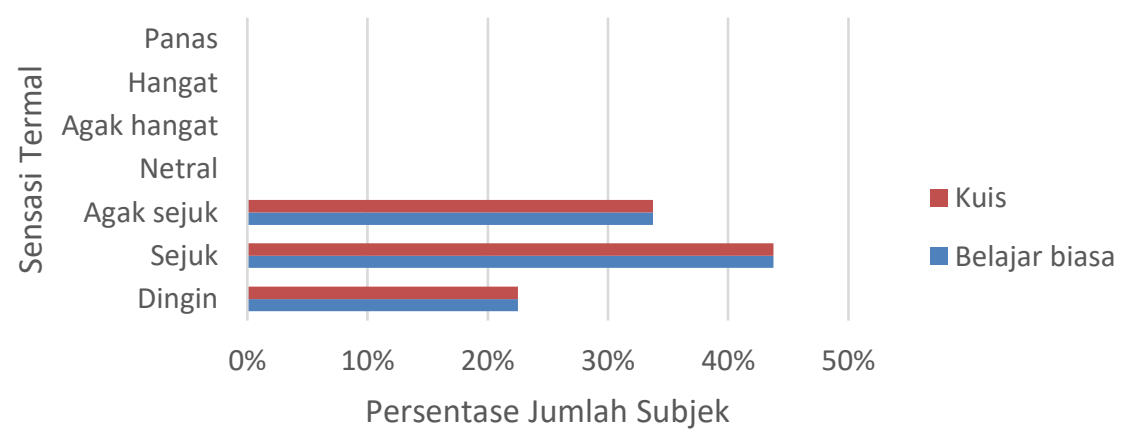

Gambar 2. Persentase distribusi subjek mengenai sensasi termal di siang hari (suhu ruang $19^{\circ} \mathrm{C}, \mathrm{RH} 58 \%$ ) 
Kelembaban udara pada suhu ruangan $19^{\circ} \mathrm{C}$ di pagi hari adalah $\pm 53 \%$ sedangkan di siang hari adalah $60 \%$. Hal ini disebabkan karena suhu diluar ruangan di pagi hari tidak sebesar suhu diluar ruangan di siang hari sehingga kelembaban udaranya lebih besar di siang hari. Ruangan memiliki banyak bukaan (jendela) di sepanjang dinding sebelah barat dan timur sehingga cahaya matahari dapat masuk. Radiasi matahari yang semakin tinggi menyebabkan penguapan air di udara dengan intensitas tinggi sehingga kelembaban udara juga semakin tinggi.

\section{Analisis Sensasi Termal pada Pengaturan Suhu Ruang $23^{\circ} \mathrm{C}$}

Pada Gambar 3, terdapat 9\% responden menunjukkan respon merasa sejuk, 54\% menunjukkan respon merasa agak sejuk dan $32 \%$ menunjukkan respon merasa netral, baik untuk aktivitas kuis dan kuliah biasa. Pada Gambar 4 , terdapat $21 \%$ responden menunjukkan respon merasa agak sejuk, $59 \%$ menunjukkan respon merasa netral dan $20 \%$ menunjukkan respon merasa agak hangat, baik untuk aktivitas kuis dan kuliah biasa. Dalam studi ini, dapat disimpulkan pengaturan suhu ruangan $23^{\circ} \mathrm{C}$ dengan kelembaban udara baik 55\% maupun $66 \%$ merupakan kondisi suhu yang dapat diterima.

\section{Analisis Sensasi Termal pada Pengaturan Suhu Ruang $27^{\circ} \mathrm{C}$}

Pada Gambar 5, terdapat 3\% responden menunjukkan respon merasa netral, 46\% menunjukkan respon merasa agak hangat, $48 \%$ menunjukkan respon merasa hangat dan 3\% menunjukkan respon merasa panas untuk aktivitas kuliah biasa. Sedangkan untuk aktivitas mengerjakan kuis, 3\% responden menunjukkan respon merasa netral, 44\% menunjukkan respon merasa agak hangat, 49\% menunjukkan respon merasa hangat dan 5\% menunjukkan respon merasa panas. Pada Gambar 6, terdapat 4\% responden menunjukkan respon merasa netral, $41 \%$ menunjukkan respon merasa agak hangat, $49 \%$ menunjukkan respon merasa hangat dan $6 \%$ menunjukkan respon merasa panas untuk aktivitas kuliah biasa. Sedangkan untuk aktivitas mengerjakan kuis, $1 \%$ responden menunjukkan respon merasa netral, 38\% menunjukkan respon merasa agak hangat, $51 \%$ menunjukkan respon merasa hangat dan $11 \%$ menunjukkan respon merasa panas. Dalam studi ini, dapat disimpulkan pengaturan suhu ruangan $27^{\circ} \mathrm{C}$ dengan kelembaban udara $62 \%$ maupun $72 \%$ merupakan kondisi suhu yang tidak dapat diterima.

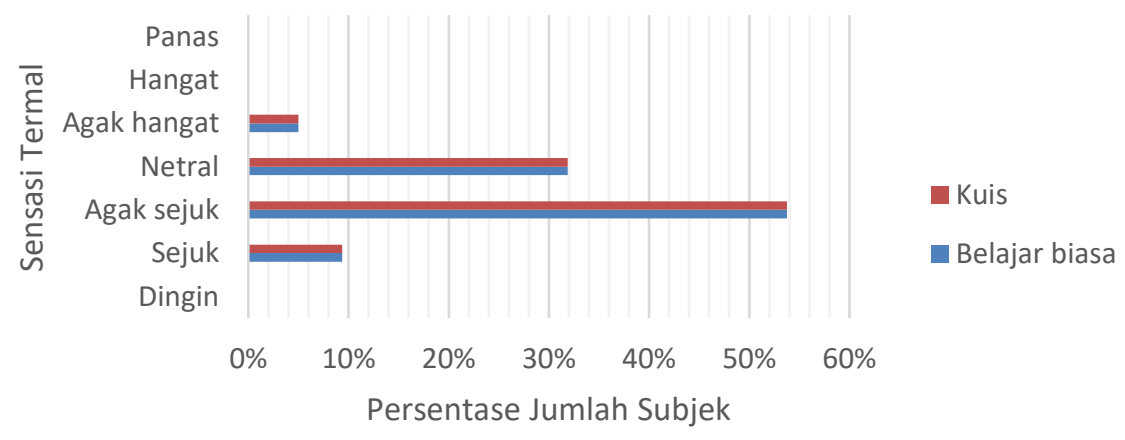

Gambar 3. Persentase distribusi subjek mengenai sensasi termal di pagi hari (suhu ruang $23^{\circ} \mathrm{C}, \mathrm{RH} 55 \%$ )

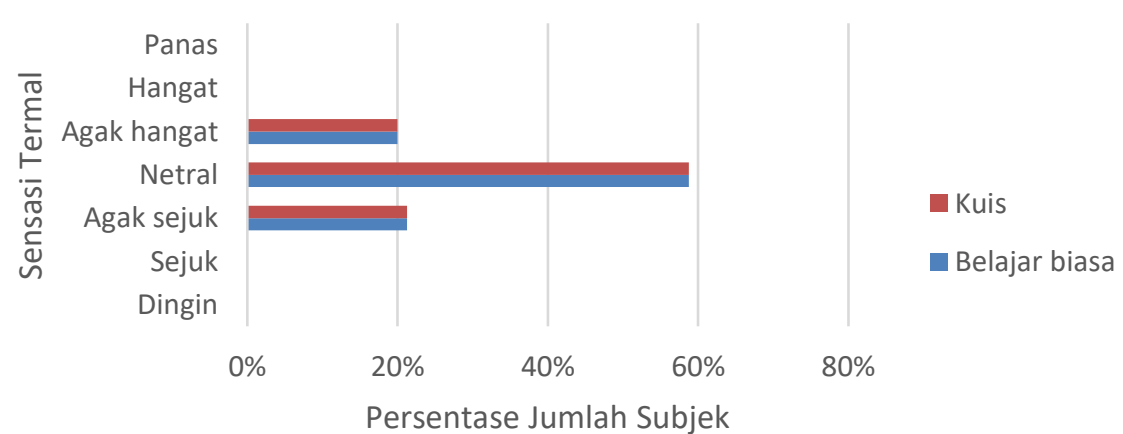

Gambar 4. Persentase distribusi subjek mengenai sensasi termal di siang hari (suhu ruang $23^{\circ} \mathrm{C}, \mathrm{RH} 66 \%$ ) 


\section{Analisis Sensasi Termal pada Pengaturan Suhu Ruang $30^{\circ} \mathrm{C}$}

Pada Gambar 7, terdapat 3\% responden menunjukkan respon merasa agak hangat, 44\% menunjukkan respon merasa hangat, dan 54\% menunjukkan respon merasa panas untuk aktivitas kuliah biasa. Sedangkan untuk aktivitas mengerjakan kuis, 71\% menunjukkan respon merasa hangat dan $89 \%$ menunjukkan respon merasa panas. Pada Gambar 8, terdapat 28\% menunjukkan respon merasa hangat dan 72\% menunjukkan respon merasa panas untuk aktivitas kuliah biasa. Sedangkan untuk aktivitas mengerjakan kuis, $16 \%$ menunjukkan respon merasa hangat dan $84 \%$ menunjukkan respon merasa panas. Dalam studi ini, dapat disimpulkan pengaturan suhu ruangan $30^{\circ} \mathrm{C}$ dengan kelembaban udara baik $63 \%$ maupun $77 \%$ merupakan kondisi suhu yang tidak dapat diterima.

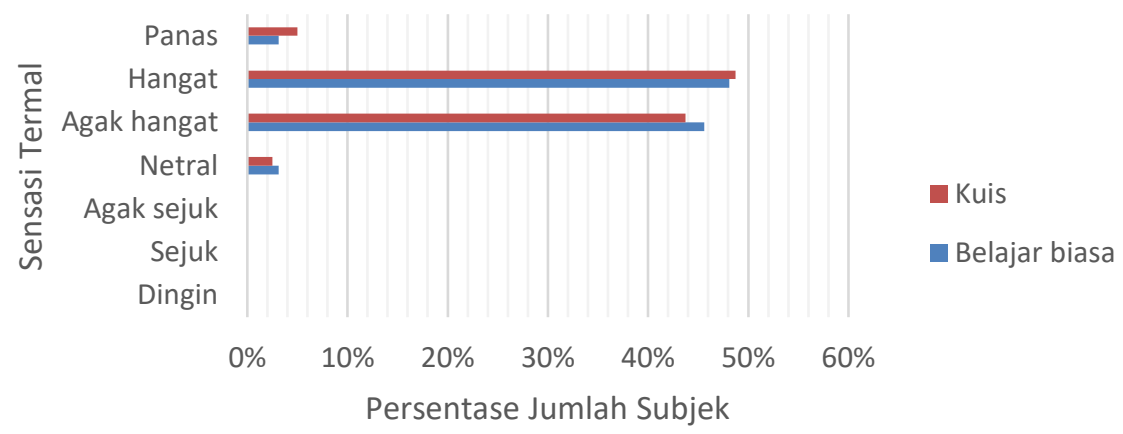

Gambar 5. Persentase distribusi subjek mengenai sensasi termal di pagi hari (suhu ruang $27^{\circ} \mathrm{C}, \mathrm{RH} 62 \%$ )

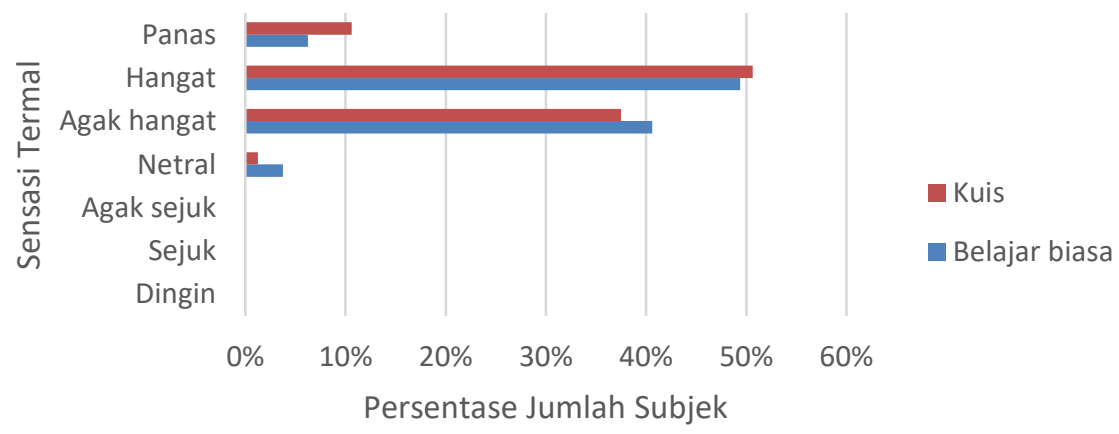

Gambar 6. Persentase distribusi subjek mengenai sensasi termal di siang hari (suhu ruang $27^{\circ} \mathrm{C}, \mathrm{RH} 72 \%$ )

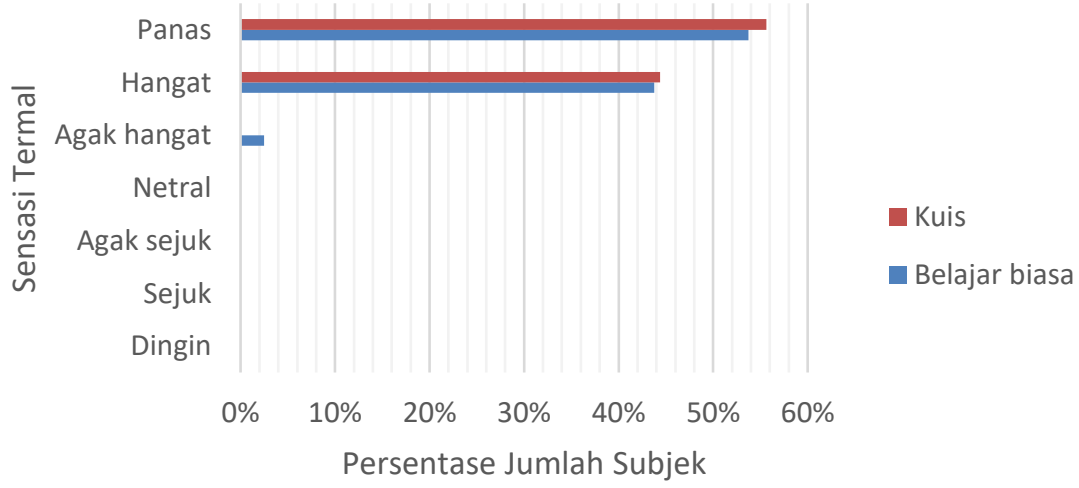

Gambar 7. Persentase distribusi subjek mengenai sensasi termal di pagi hari (suhu ruang $30^{\circ} \mathrm{C}, \mathrm{RH} 63 \%$ ) 


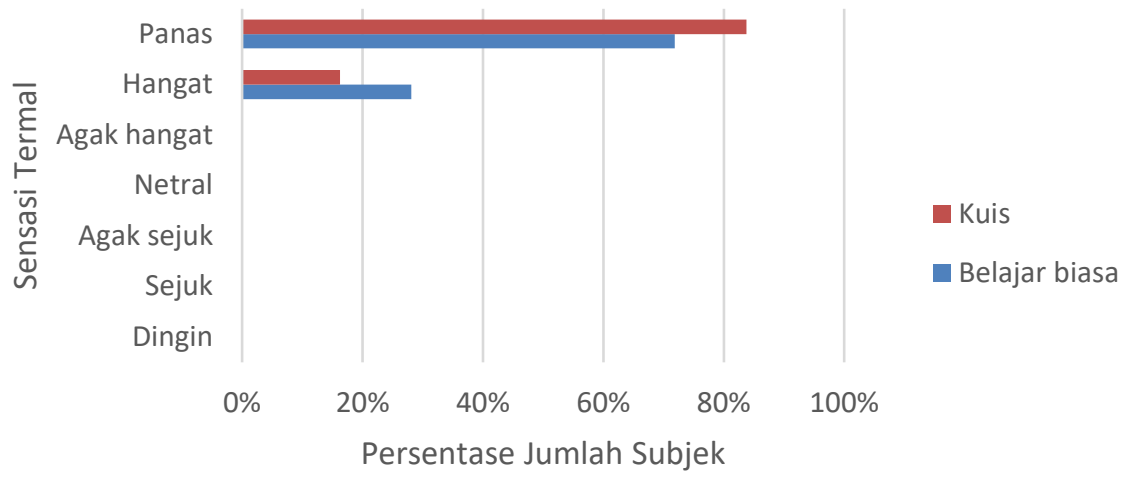

Gambar 8. Persentase distribusi subjek mengenai sensasi termal di siang hari (suhu ruang $30^{\circ} \mathrm{C}, \mathrm{RH} 77 \%$ )

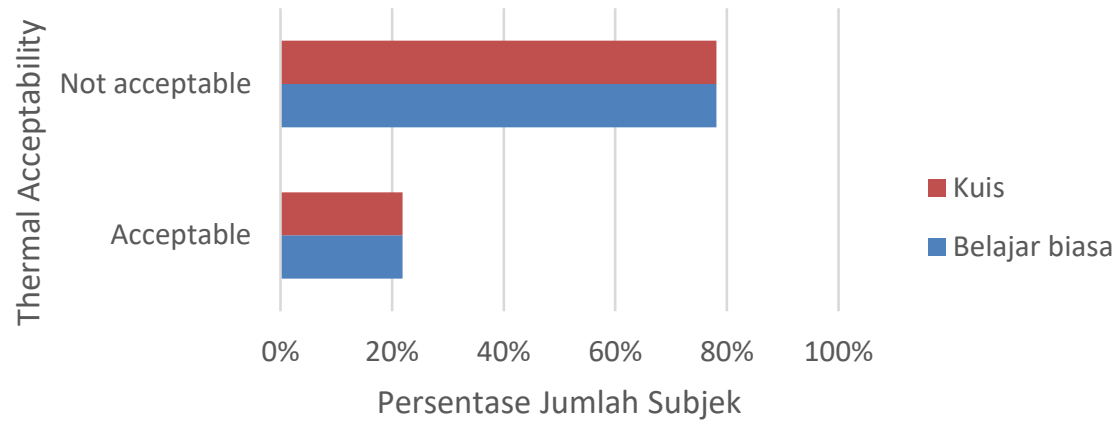

Gambar 9. Persentase distribusi subjek mengenai thermal acceptability di pagi hari (suhu ruang $19^{\circ} \mathrm{C}$, RH $53 \%$ )

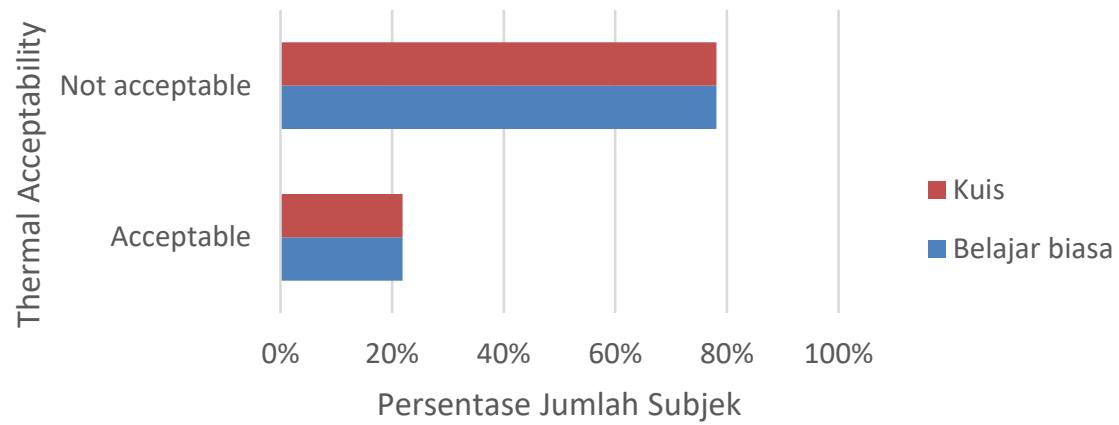

Gambar 10. Persentase distribusi subjek mengenai thermal acceptability di siang hari (suhu ruang $19^{\circ} \mathrm{C}, \mathrm{RH} 58 \%$ )

\section{Analisis Thermal Acceptability pada suhu $19^{\circ} \mathrm{C}$}

Gambar 9 dan Gambar 10 menunjukkan bahwa subjek tidak dapat menerima suhu $19^{\circ} \mathrm{C}$ baik pada RH 53\% dan $58 \%$ serta pada saat melakukan aktivitas kuliah biasa dan mengerjakan kuis. Dengan demikian dapat disimpulkan mahasiswa tidak dapat menerima sensasi dingin pada saat melakukan kegiatan kuliah dan mengerjakan soal kuis.

\section{Analisis Thermal Acceptability pada suhu $23^{\circ} \mathrm{C}$}

Gambar 11 dan Gambar 12 menunjukkan bahwa subjek dapat menerima suhu $23^{\circ} \mathrm{C}$ baik pada RH $55 \%$ dan $66 \%$ serta pada saat melakukan aktivitas kuliah biasa dan mengerjakan kuis. 


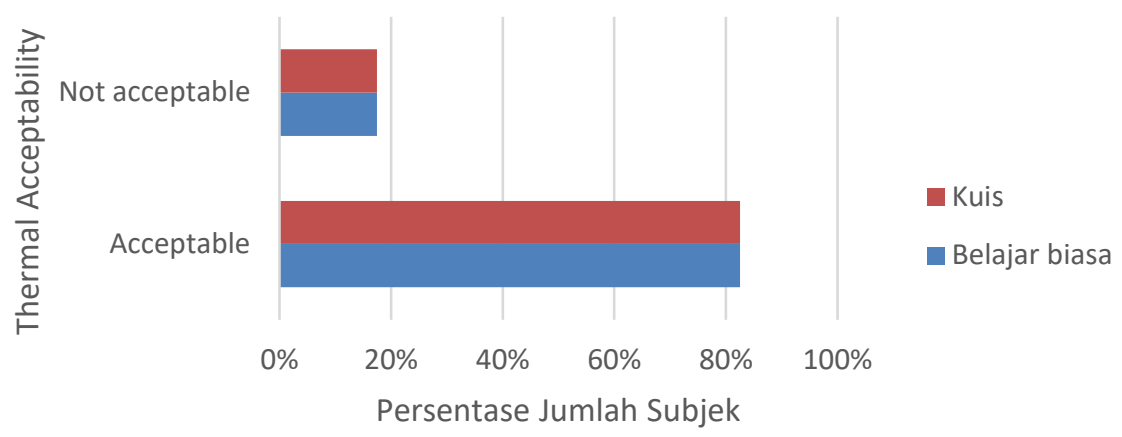

Gambar 11. Persentase distribusi subjek mengenai thermal acceptability di pagi hari (suhu ruang $23^{\circ} \mathrm{C}, \mathrm{RH} 53 \%$ )

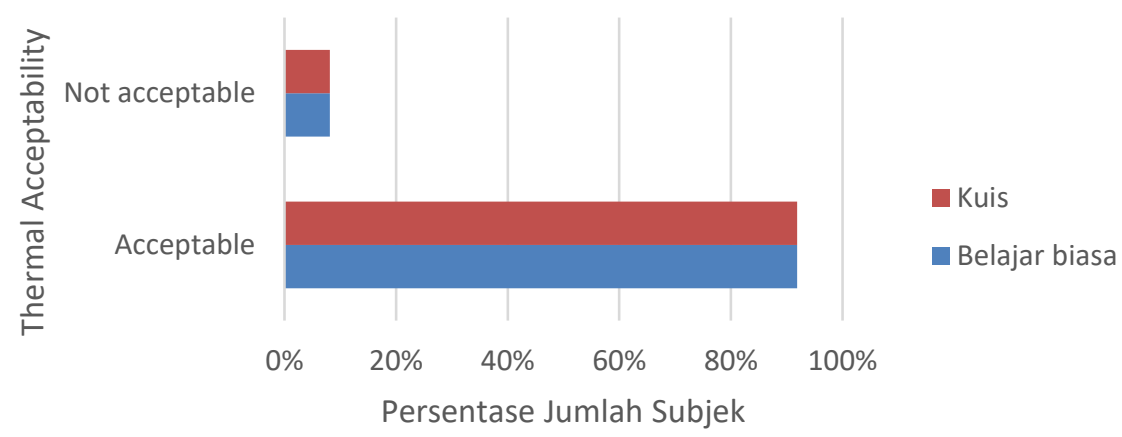

Gambar 12. Persentase distribusi subjek mengenai thermal acceptability di siang hari (suhu ruang $23^{\circ} \mathrm{C}$, RH $58 \%$ )

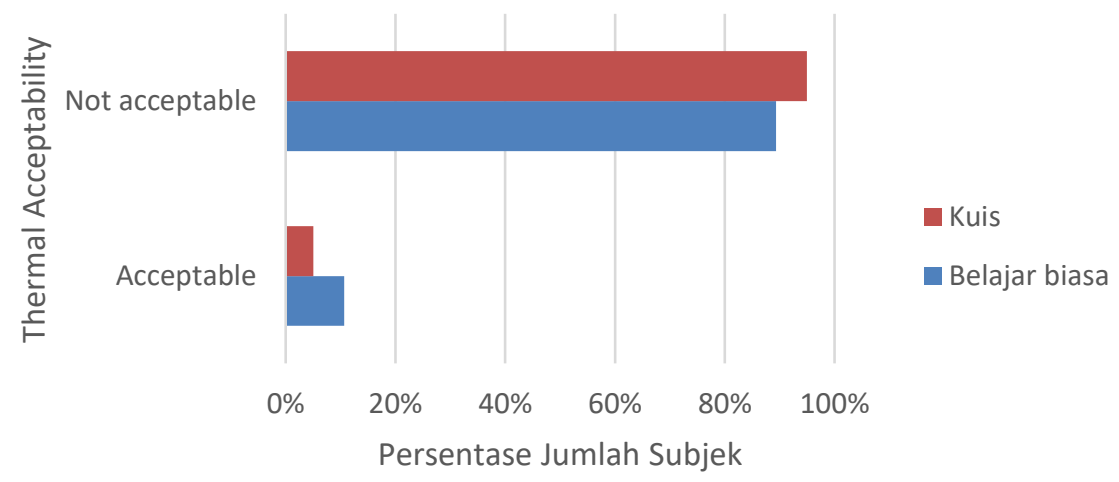

Gambar 13. Persentase distribusi subjek mengenai thermal acceptability di pagi hari (suhu ruang $27^{\circ} \mathrm{C}$, $\mathrm{RH} 62 \%$ )

\section{Analisis Thermal Acceptability pada suhu $27^{\circ} \mathrm{C}$}

Gambar 13 dan Gambar 14 menunjukkan bahwa subjek tidak dapat menerima suhu $27^{\circ} \mathrm{C}$ baik pada RH $62 \%$ dan $72 \%$ serta pada saat melakukan aktivitas kuliah biasa dan mengerjakan kuis.

\section{Analisis Thermal Acceptability pada suhu $30^{\circ} \mathrm{C}$}

Gambar 15 dan Gambar 16 menunjukkan bahwa subjek tidak dapat menerima suhu $30^{\circ} \mathrm{C}$ baik pada RH $63 \%$ dan $77 \%$ serta pada saat melakukan aktivitas kuliah biasa dan mengerjakan kuis. 


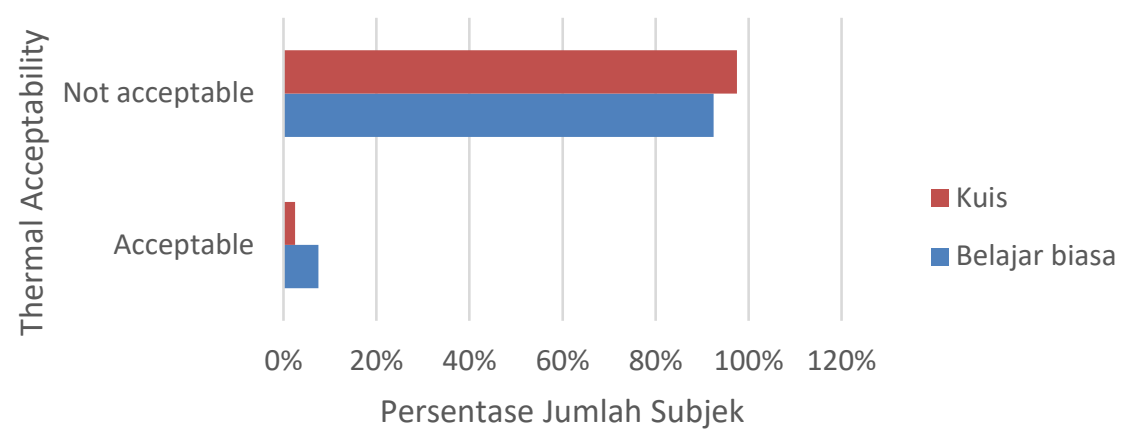

Gambar 14. Persentase distribusi subjek mengenai thermal acceptability di siang hari (suhu ruang $27^{\circ} \mathrm{C}, \mathrm{RH} 72 \%$ )

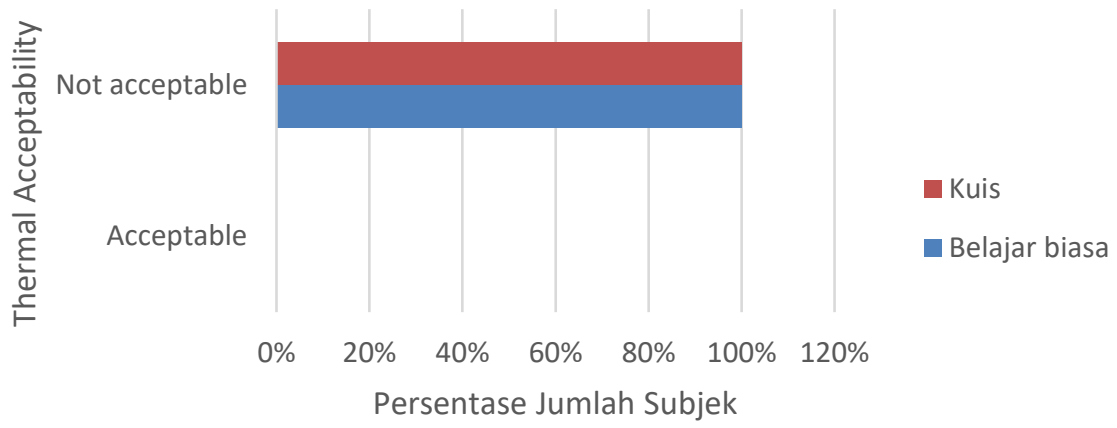

Gambar 15. Persentase distribusi subjek mengenai thermal acceptability di pagi hari (suhu ruang $30^{\circ} \mathrm{C}$, $\mathrm{RH} 63 \%$ )

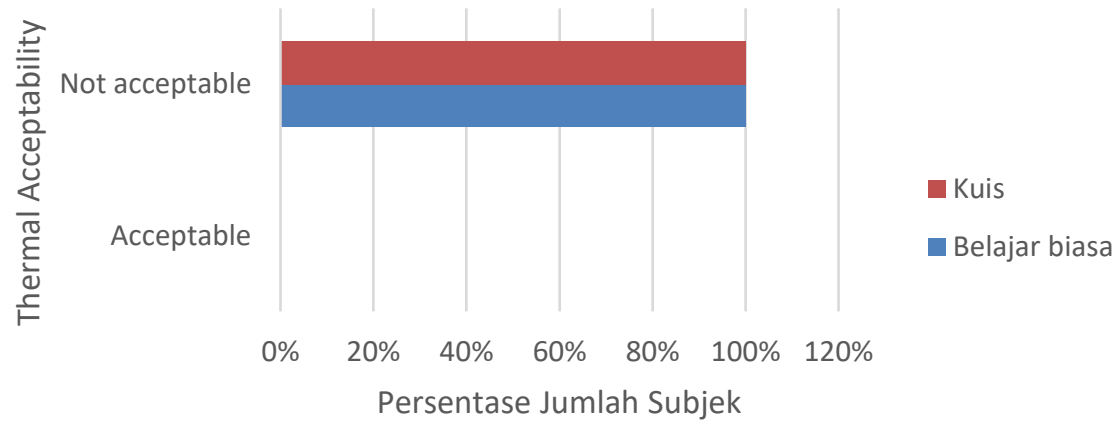

Gambar 16. Persentase distribusi subjek mengenai thermal acceptability di siang hari (suhu ruang $30^{\circ} \mathrm{C}, \mathrm{RH} 77 \%$ )

Berdasarkan hasil penelitian yang telah dipaparkan di atas, subjek merasa nyaman melakukan aktivitas kuliah dan mengerjakan kuis pada suhu $23^{\circ} \mathrm{C}$ dengan kondisi kelembaban udara antara 55\% sampai 66\%. Pada kondisi suhu $27^{\circ} \mathrm{C}$, sensasi termal subjek sudah berubah cenderung ke hangat, dan pada suhu $30^{\circ} \mathrm{C}$ sensasi termal subjek juga berubah cenderung ke panas. Subjek saat melakukan aktivitas kuliah biasa pada suhu $19^{\circ} \mathrm{C}$ dan $23^{\circ} \mathrm{C}$ sensasi termalnya tidak berubah saat melakukan aktivitas mengerjakan kuis, namun pada saat suhu berada pada $27^{\circ} \mathrm{C}$ dan $30^{\circ} \mathrm{C}$, sensasi termal pada saat kuliah biasa berbeda dengan mengerjakan kuis. Ada kecenderungan subjek mulai tidak nyaman pada saat mengerjakan kuis. Subjek ketika pada kondisi suhu dingin sampai normal, pengaruh beban aktivitas kuliah biasa tidak berbeda dengan beban aktivitas mengerjakan kuis, namun pada saat suhu mencapai hangat dan selebihnya, beban aktivitas mulai berpengaruh. Subjek merasa lebih gerah pada saat mengerjakan kuis bila dibandingkan dengan aktivitas kuliah biasa. Dapat disimpulkan pada suhu tinggi, beban aktivitas berpengaruh 
terhadap sensasi kenyamanan termal sedangkan pada suhu dingin ke normal, beban aktivitas tidak berpengaruh terhadap sensasi kenyamanan termal.

\section{Kesimpulan}

Keluaran penelitian berupa identifikasi suhu kenyamanan termal pada saat mahasiswa melakukan aktivitas kuliah di ruang kuliah FTI UAJY dan dampak yang dirasakan oleh mahasiswa yang terlibat. Kesimpulan penelitian dapat dikelompokkan berdasarkan hasil analisis sensasi termal dan analisis thermal acceptability. Berdasarkan analisis sensasi termal diperoleh informasi bahwa kondisi suhu yang dapat diterima oleh mahasiswa untuk melakukan aktivitas kuliah dan kuis adalah kondisi suhu ruang kuliah $23^{\circ} \mathrm{C}$ dengan kelembaban udara baik $55 \%$ maupun $66 \%$. Kondisi ruang kuliah pada $19^{\circ} \mathrm{C}, 27^{\circ} \mathrm{C}$, dan $30^{\circ} \mathrm{C}$ dengan beragam nilai kelembaban udara yang terjadi merupakan kondisi suhu yang tidak dapat diterima oleh mahasiswa saat melakukan aktivitas kuliah dan melaksanakan kuis. Hasil analisis thermal acceptability memberikan kesimpulan bahwa mahasiswa dalam melaksanakan aktivitas kuliah dan melaksanakan kuis dapat menerima kondisi suhu ruang kuliah $23^{\circ} \mathrm{C}$ baik pada RH 55\% dan $66 \%$. Sedangkan pada kondisi suhu $19^{\circ} \mathrm{C}, 27^{\circ} \mathrm{C}$, dan $30^{\circ} \mathrm{C}$, mahasiswa tidak menerima keadaan tersebut saat melakukan aktivitas kuliah dan mengerjakan kuis. Hasil ini dapat dijadikan sebagai bahan rekomendasi bahwa saat kegiatan perkuliahan berlangsung, mesin AC dapat diatur sehingga mampu mengondisikan suhu ruang sebesar $23^{\circ} \mathrm{C}$. Penelitian pada tahap selanjutnya dilakukan untuk menghitung konversi energi yang diperlukan untuk mewujudkan kondisi suhu ruang beserta analisis ekonomi/keuangan. Dampak penghematan penggunaan energi dapat dikaji lebih dalam terkait dengan total energi yang diperlukan seluruh ruang kuliah yang ada di Universitas Atma Jaya Yogyakarta.

Ucapan Terima Kasih: Terima Kasih kepada Lembaga Penelitian dan Pengabdian Masyarakat (LPPM) Universitas Atma Jaya Yogyakarta yang telah mendanai penelitian ini.

\section{Referensi}

[1] L. Susanti \& N. Aulia, "Evaluasi kenyamanan Termal Ruang Sekolah SMA Negeri di Kota Padang," Jurnal Optimasi Sistem Industri, vol. 12, no. 1, April 2013.

[2] F. Idealistina, "Model termoregulasi tubuh untuk penentuan besaran kesan termal terbaik dalam kaitannya dengan kinerja manusia," Disertasi Magister Institut Teknologi Bandung, tidak dipublikasikan.

[3] ISO 7730, Moderate thermal environments - determination of the PMV and PPD indices and specifications for thermal comfort, second edition. Geneva, Switzerland.: International Organisation for Standardisation, 1994.

[4] ASHRAE, Thermal environmental condition for human occupancy (ASHRAE standard 55-56). ASHRAE: Atlanta US, 1992.

[5] P. O. Fanger, Thermal comfort. Malabar, FL, USA: Robert E. Krieger Publishing Company, 1982.

[6] M. Hussin, M. R. Ismail, M. S. Ahmad, "Subjective perception of thermal comfort study in air-conditioned university laboratories", Journal of Social and Behavioral Sciences, vol. 91, hal. 192-200, 2013.

[7] T. H. Karyono, J. Sulistiawan, E. Sri, \& Y. Triswanti, "Thermal comfort studies in naturally ventilated buildings in Jakarta, Indonesia,” Journal of Buildings, vol. 5. hal. 917-932, August 2015.

[8] G. Lippsmeier, Bangunan tropis. Jakarta: Erlangga, 1980.

[9] R. Kosonen \& F. Tan, "Assessment of productivity loss in air-conditioned buildings using PMV index," Journal of Energy and Buildings, vol. 36, hal. 987-993, 2004.

[10] J. Singh, "Health, comfort and productivity in indoor environment," Journal of Indoor Built Environment, vol. 5, hal. 22-33, 1996.

[11] S. V. Szokolay, Manual of teopical housing and building. Bombay: Orient Langman, 1973.

[12] F. Kerlinger, Foundations of behavioral research, second edition. Holt, Rinehart and Winston, 1973.

[13] M. Goldman, H. Gvirtzman, M. Meju, \& V. Shtivelman, "Hydrogeophysical case studies at the regional scale," Hydrogeophysics, Springer, hal. 361-390, 2005.

[14] ASHRAE Standard 55-2004, Thermal environmental conditions for human occupancy. Atlanta: American Society of Air-Conditioning, Heating and Refrigerating Engineers, Inc. Fanger, P O. 1970. "Thermal Comfort.” Danish Technical Press, 2004. 